\title{
Trajetória e narrativas de Goya Lopes: por uma moda brasileira mais plural
}

Trajectory and narratives of Goya Lopes: for a more plural Brazilian fashion 


\section{Bruna Carmona Bonifácio ${ }^{1}$}

ORCID: https://orcid.org/0000-0002-3970-2400

\section{Ronaldo de Oliveira Corrêa ${ }^{2}$}

ORCID: https://orcid.org/0000-0003-1894-1944

[resumo] Neste artigo, esperamos descrever eventos relacionados à atuação de Goya Lopes, artista e designer negra que trabalha majoritariamente com a temática afro-brasileira, como articuladora política de um projeto de moda brasileira mais diversa. Para tanto, temos como objetivo mapear e descrever experiências da sua trajetória e do seu trabalho, além de suas estratégias como membro titular do Colegiado Setorial de Moda do Ministério da Cultura do Brasil. Por procedimento metodológico, recorremos à análise de fontes heterogêneas, como entrevistas concedidas por Goya, documentos do seu acervo pessoal, textos diversos sobre a designer, site e redes sociais da empresa Goya Lopes Design Brasileiro. Como resultado, pretendemos reconstruir eventos sobre o desenvolvimento de um projeto de moda mais plural, explicitar as adesões da designer a redes de relações afro-brasileiras, além de destacar o protagonismo de Goya Lopes no design brasileiro feito por mulheres.

\section{[palavras-chave] Goya Lopes. Design de moda. Design afro-brasileiro. Mulheres designers. Política de moda.}

[abstract] In this article we hope to describe events related to the performance of Goya Lopes, a black artist and designer who works mostly with the Afro-Brazilian theme, as a political articulator for a more diverse Brazilian fashion project. To this end, we aim to map and describe experiences about her career, work and strategies as a full member of the Sectorial Collegiate of Fashion of the Ministry of Brazilian Culture. By methodological procedure, we resort to the analysis of heterogeneous sources, such as interviews given by Goya, documents from the designer's personal collection, various texts about the designer, website and social networks of the company Goya Lopes Design Brasileiro. As a result, we intend to reconstruct events about the development of a more plural fashion project, explain the designer's adhesions to networks of Afro-Brazilian relations, in addition to highlighting the role of Goya Lopes in Brazilian design made by women.

[keywords] Goya Lopes. Fashion design. Afro-brazilian design. Women designers. Fashion politics.

Recebido em: 30-03-2020

Aprovado em: 11-05-2020

\footnotetext{
${ }^{1}$ Doutoranda no Programa de Pós-Graduação em Design da UFPR. E-mail: bruna.c.bonifacio@gmail.com. Lattes: http://Lattes.cnpq.br/6963724725256888.

2 Doutor em Ciências Humanas pelo PPGICH/UFSC. Professor no Departamento de Design da UFPR, do Programa de Pós-Graduação na mesma instituição e professor do Programa de Pós-Graduação em Tecnologia da UTFPR. E-mail: rcorrea@ufpr.br. Lattes: http://lattes.cnpq.br/3869130149433615.
} 


\section{Introdução}

0 presente artigo tem como origem dados coletados e analisados na dissertação de Bonifácio ${ }^{3}$, na qual desenvolvemos uma pesquisa sobre experiências no design de superfície das designers Goya Lopes e Renata Rubim, sob a perspectiva da história das mulheres, o trabalho de mulheres e o trabalho delas no design. Dialogamos com autoras e autores do design, da cultura material, da história e da sociologia, além de pesquisadoras de perspectiva feminista, buscando cotejar o embasamento teórico com o material advindo de estudo documental sobre o tema, somado às narrativas de aprendizado, trabalho e trajetórias das designers.

Importa registrar que para descrever os eventos que são o tema deste artigo foi realizada pesquisa empírica, baseada em procedimentos da História Oral, a partir de autores como Verena Alberti (2004) e José Carlos S. B. Meihy (2005). Sendo ela somente possível graças à colaboração das interlocutoras que dividiram com a pesquisadora narrativas e documentos de acervos pessoais. As perguntas relacionadas às condições materiais para que as designers desenvolvessem seus trabalhos, sobre o que elas fazem, de que modo executam, o que consideram importante trabalhar, como compreendem seus vínculos com as práticas do design, bem como as informações sobre enfrentamentos que permitiram ou impediram modos de fazer e considerações acerca do valor atribuído socialmente ao design de superfície e ao design de moda quando comparados a outros tipos de design, foram respondidas e compartilhadas em entrevistas concedidas pelas designers. Foi um posicionamento político e ético ouvi-las e registrar a reconstrução dessas histórias em texto.

Adrian Forty (2007), Rafael Cardoso (2008) e Rodrigo M. Pereira (2014), autores cujas perspectivas nos filiamos, consideram design como uma atividade de criação, projeto e produção realizada por sujeitos de áreas diversas, além das e dos designers profissionais. A autora Isabel Campi (2003) adensa o debate sobre sujeitos, espaços e eventos do design ao criticar um relato canônico da história desse meio que exclui "uma enorme quantidade de obras, autores, instituições e empresas surgidas em países e regiões geográfica, cultural ou economicamente distantes do centro" (CAMPI, 2003, p. 91, tradução nossa). ${ }^{4}$ Assim como a autora, entendemos necessário reconstruir relatos e existências, expandindo os limites históricos, metodológicos e críticos sobre o design e sua historiografia.

Consideramos este artigo como pertencente aos estudos sobre cultura material, filiando-nos ao trabalho de Daniel Miller (2013) e sua compreensão de cultura material como uma área em que se realizam investigações e análises sobre práticas do cotidiano por meio de artefatos. Eles são tidos como participantes de processos e modos pelos quais as pessoas

\footnotetext{
3 BONIFÁCI0, Bruna Carmona. Experiências de mulheres no design de superfície: narrativas sobre trabalho e trajetórias de Goya Lopes e Renata Rubim. 2019. 197 f. Dissertação (Mestrado em Design) Programa de Pós-Graduação em Design, Universidade Federal do Paraná, Curitiba, 2019.

${ }^{4}$ Tradução nossa para: "Una enorme cantidad de obras, autores, instituciones y empresas surgidos em países y regiones alejados geográfica, cultural o economicamente del centro”.
} 
criam a si mesmas. Nessa perspectiva, o movimento de duplo sentido problematizado por Miller (2013) é perpassado por questões de região, raça, gênero e classe, como pretendemos explicitar no decorrer do texto sobre as vivências da designer Goya Lopes.

\section{Goya Lopes, artista e designer}

Maria Auxiliadora dos Santos Goya Lopes (figura 1) nasceu em 7 de maio de 1954, em Salvador (Bahia). Cresceu e residiu na cidade durante sua infância, exceto no ano de 1961 quando morou na França com os pais e os dois irmãos mais velhos. Nesse período, uma professora da École Élémentaire Martinelli recomendou aos pais que incentivassem o seu desenvolvimento artístico, pois notou que o desenho de Goya era diferente do de outras crianças; e assim aconteceu, principalmente por iniciativa de seu pai.

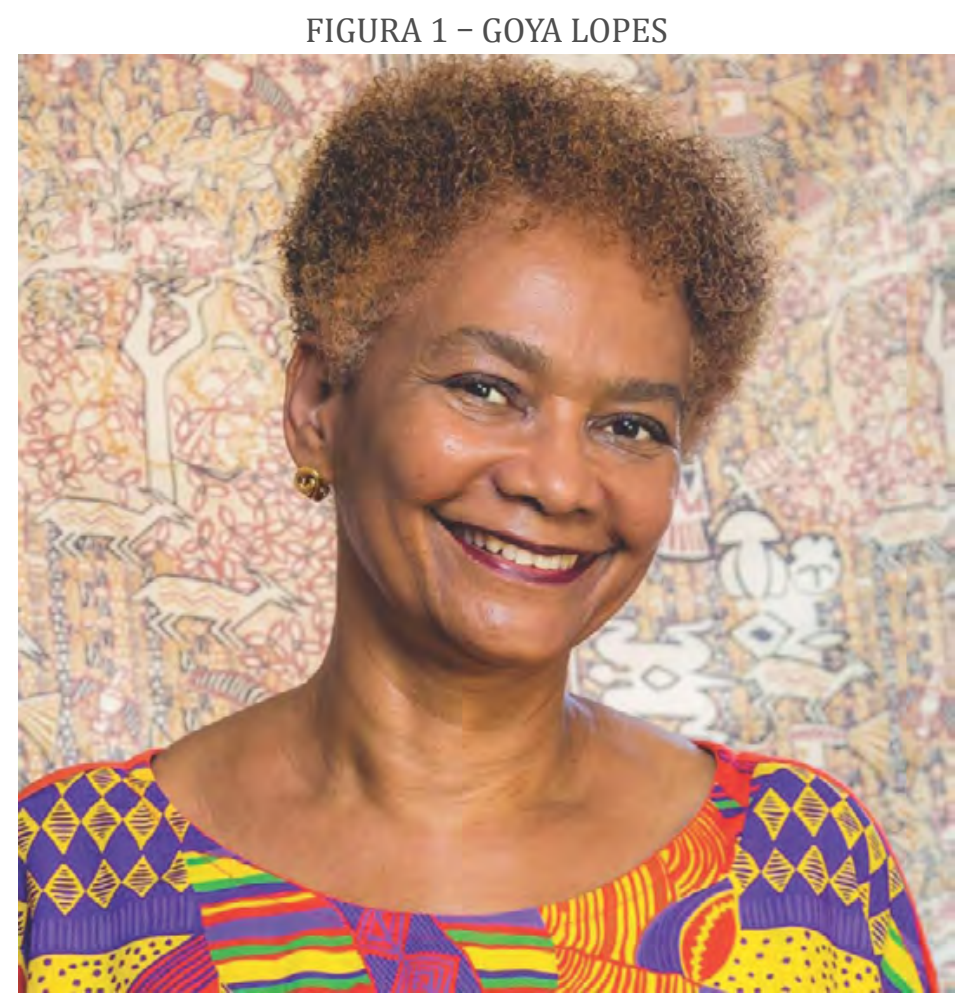

FONTE: LOPES, Goya. Imagem do perfil da designer. Bahia: 2017. Imagens obtidas no site Goya Lopes Design Brasileiro. Disponível em: https://www.facebook.com/goya.lopes. Acesso em: 1. mar. 2020.

A biografia da família de Goya Lopes auxilia na compreensão sobre as condições materiais existentes para seu aprendizado e sua trajetória como artista e designer. Os pais lhe proporcionaram boa educação, com práticas relacionadas à literatura, ao cinema, à música e às artes plásticas em sua rotina. Sua mãe a apoiou na decisão de estudar artes, embora preferisse que a profissão da filha fosse a de arquiteta: "Mesmo achando que ser artista não 
era uma profissão. Naquela época ainda, hein!" (informação verbal). ${ }^{5}$ Sua família era bem relacionada, possuía condições para viajar, conhecer outras cidades e países.

Formou-se em Artes Plásticas pela Universidade Federal da Bahia (1976), época durante a qual desenvolveu trabalhos principalmente nas áreas de pintura e mosaico. Por causa do seu interesse por história da arte africana e arqueologia, frequentou no mesmo período o curso de História da Universidade Católica de Salvador, o que incentivou Goya a estagiar na área de restauro do Instituto de Patrimônio Artístico e Cultural da Bahia (19761977). Especializou-se em Design, Museologia, Expressão e Comunicação Visual pela Universitá Internazionale Dell'Arte di Firenze, na Itália (1978-1979), momento em que tanto foi estimulada a utilizar seus saberes artísticos no design de estamparia em superfície têxtil, quanto teve acesso a outras técnicas criativas - litografia, na Stamperia D’Arte Gráfica Santa Reparata, e procedimentos de estamparia corrida no estágio com a designer Linda Ieromonti - que foram incluídas em seus processos de criação. Ao retornar ao Brasil nos anos 1980, sua participação em cursos teve como enfoque a capacitação para o mercado de trabalho e gestão de empresas. A formação na área de moda aconteceu mais tarde, na especialização em Design de Moda pelo Instituto Brasileiro de Moda da Bahia (2009) e no projeto estruturante Moda Design Bahia, da Secretaria de Ciência, Tecnologia e Inovação da Bahia.

Até o ano de 2017, Goya apresentava-se em seu site Goya Lopes Design Brasileiro como mulher, negra, baiana, empresária, artista e designer (LOPES, 2018). Considerando os termos de identificação escolhidos por ela, daremos relevo a alguns eventos de sua trajetória de trabalho.

Em 1983, no seu retorno ao Brasil, Lopes mapeou a indústria têxtil da Bahia, porém, o resultado mostrou-lhe pouca opção de trabalho, enquanto o mercado na capital de São Paulo estava mais próspero para atuar na criação de design de superfície, focado em estamparia. Por esse motivo, Goya ativou sua rede de relações artísticas, culturais e afetivas para viabilizar o movimento de residir em São Paulo, e assim aconteceu. Sobre estar em São Paulo nos anos 1980 e tentar entrar no mercado de trabalho, relatou:

Tem esse problema de indicação, e no início, é muito difícil, principalmente pra nordestino. Hoje ainda tem, imagina há 30 anos atrás a dificuldade [...] 0 nordestino era visto de uma maneira muito mais braçal do que intelectual, nesse sentido. (INFORMAÇÃO VERBAL) ${ }^{6}$

Por compreender essa dinâmica como preconceituosa, a designer assumiu o posicionamento de abordar a história e o discurso afro-brasileiro em suas criações estampadas e, com o tempo, ela entendeu cada vez mais a necessidade de se articular em e com os grupos que passam por impedimentos semelhantes aos que vivencia, como um modo de resistência e possibilidade de acesso a alguns circuitos que lhe interessam.

\footnotetext{
5 Entrevista de Goya Lopes, Salvador, janeiro de 2018.

${ }^{6}$ Entrevista de Goya Lopes, Salvador, janeiro de 2018.
} 
No período em São Paulo, ela atuou em projetos para a empresa Alpargatas ${ }^{7}$, na linha Madrigal, com temas relacionados à cultura popular brasileira e nordestina; também realizou criações para a linha de decoração infantil da empresa Carol e Geada ${ }^{8}$ e para a linha de decoração da empresa Aziz Nader ${ }^{9}$.

Nesse momento, Goya acompanhava o trabalho de Maria Henriqueta Gomes ${ }^{10}$ como empresária responsável pela Arte Nativa Aplicada - conhecida também pela sigla ANA -, empresa de pequeno porte que, desde 1976, tornava-se referência em tecidos estampados com elementos da cultura brasileira. 0 intuito da marca era apresentar uma nova proposta para o design de estamparia no Brasil, "fazer um desenho industrial baseado nas origens nacionais", com inspirações em coletivos indígenas, suas cestarias, cerâmicas, grafismos, pinturas corporais e artes plumárias (MUSEU DA CASA BRASILEIRA, 2018). Henriqueta ministrava palestras sobre seus projetos, as quais Goya frequentava, bem como a loja da marca: "Eu ia à loja e ficava babando. Meu deus do céu! Já pensou se eu puder fazer isso com o tecido afro-brasileiro?" (informação verbal). ${ }^{11}$

ANA e Henriqueta tornaram-se grandes inspirações para a designer, que, ao ver a linha Madrigal ser descontinuada pela Alpargatas e tendo que procurar outra opção de trabalho, ponderou sobre as questões organizacionais de ter uma fábrica como a ANA, com estrutura física e funcionários, e entendeu a vontade de empreender em seu negócio próprio de forma similar ao de Henriqueta.

\section{Artista, designer e empresária negra}

Goya, em entrevista à autora, comenta que "Hoje sim! As pessoas querem o afro, mas você pense em [19]83-84. Ninguém. Isso é coisa de carnaval! Isso é coisa de candomblé!" (informação verbal). ${ }^{12}$ Lopes entende de forma crítica que a decisão por ser empresária de um projeto com a temática afro-brasileira era um desafio pessoal, no princípio pautado por não encontrar nenhuma outra pessoa disposta a investir em uma empresa com essa estética

\footnotetext{
Fundada em 1907 pelo escocês Robert Fraser. Em 1962, inicia a produção das sandálias Havaianas e da calça Topeka e, dois anos depois, das colchas Madrigal. Em 1970, lança o Kichute. Hoje, a Alpargatas tem sede em São Paulo, Minas Gerais, Pernambuco e Paraíba e em dez países. Disponível em: https:// www.alpargatas.com.br/\#/conheca-empresa. Acesso em: 9 fev. 2020.

${ }^{8}$ Empresa que fabricava produtos de decoração, criada por duas mulheres italianas. Entrevista de Goya Lopes, Salvador, janeiro de 2018.

9 Indústria têxtil de Americana (SP), atuante no mercado desde o ano de 1917. Disponível em: https:// www1.folha.uol.com.br/fsp/dinheiro/fi010918.htm. Acesso em: 22 fev. 2020.

10 Anna Maria Henriqueta Marsiaj tornou-se Maria Henriqueta Gomes ao se casar com Severo Fagundes Gomes. Inicialmente a parceria profissional dos dois se deu com a criação de Henriqueta para a empresa têxtil de cobertores Parahyba, instalada em São José dos Campos (SP), da família de Severo. Faleceram juntos em um acidente de helicóptero em que estavam com Ulysses Guimarães e Mora Guimarães, em 1992. Foi possível encontrar mais informações sobre a vida e a trajetória biográfica de Severo do que a de Henriqueta. Disponível em: http://www.fgv.br/cpdoc/acervo/dicionarios/verbete-biografico/ severo-fagundes-gomes. Acesso em: $16 \mathrm{fev} .2020$

11 Entrevista de Goya Lopes, Salvador, janeiro de 2018.

12 Entrevista de Goya Lopes, Salvador, janeiro de 2018.
} 
nos anos 1980. Refletindo sobre sua trajetória, ela ressalta que a construção independente do seu negócio permitiu-lhe trabalhar o tema que desejava de forma livre, com uma grande variedade de produtos, e continuar atuando simultaneamente como artista e designer.

O início de seu empreendimento se deu enquanto Goya trabalhava como funcionária pública na Secretária de Educação do Governo do Estado da Bahia (1985 a 1988). Em jornada dupla, ela desenhava suas criações que eram estampadas em camisetas artesanalmente com a técnica de máscaras e pintura manual - tratava-se de peças únicas, costuradas por sua tia e estampadas por ela. A estratégia de venda foi estabelecida pela designer com uma rede de amigos guias turísticos, que se vestiam com suas peças durantes os tours; no retorno dos passeios, ela estava no Largo do Carmo - região de maior fluxo turístico de Salvador nos anos 1980 - para receber os turistas e apresentar seu trabalho. Essa estratégia foi ressignificada e é mantida até hoje, agora a parceria se dá com os guias que, ao apresentar o centro histórico a pé para os turistas, levam-nos também à loja de Goya como um dos pontos culturais para se conhecer na cidade.

Em 1986, criou a grife Didara by Goya Lopes, inaugurando de forma mais estruturada sua empresa. 0 termo Didara foi escolhido para nomear a marca, pois significa "o que é bom" em Iorubá. ${ }^{13}$ Com o aumento da demanda, em 1987, a designer decidiu montar uma loja onde pudesse comercializar suas peças durante um horário mais amplo. 0 local escolhido ficava no Pelourinho, região que na ocasião não se tratava de um ponto turístico de alto movimento, era um destino de visitas, "mas, descolado, assim não [...] Aí eu vim praqui, quando não existia isso aqui" (informação verbal). ${ }^{14}$ Por algum tempo, Goya se esforçou para conciliar os dois trabalhos, o que foi dificultoso e resultou na sua decisão de deixar o emprego no governo.

Goya conta que, no começo, teve como seu principal público-alvo os turistas e, para tanto, sua loja no Pelourinho foi planejada para ser um espaço de apresentação de elementos culturais baianos, que proporcionasse imersão e interação entre culturas. Podemos citar, por exemplo, o fato de a loja estar em um casarão tradicional da cidade e seu interior possuir um revestimento que remete à técnica de taipa de mão com aplicação de pinturas rupestres, além do cuidado com a fisionomia e a cor dos manequins e os cabideiros e expositores de madeira, como retrata a figura 2.

\footnotetext{
13 Língua de tradição falada, surgida há milênios e que atravessou o Oceano Atlântico nos porões nos navios negreiros vindos da costa ocidental africana para sobreviver até hoje na Bahia. Disponível em: https://www.geledes.org.br/yoruba-lingua-memoria-e-parte-da-consciencia-do-povo-negro/ . Acesso em: 16 fev. 2020.

14 Entrevista de Goya Lopes, Salvador, janeiro de 2018.
} 

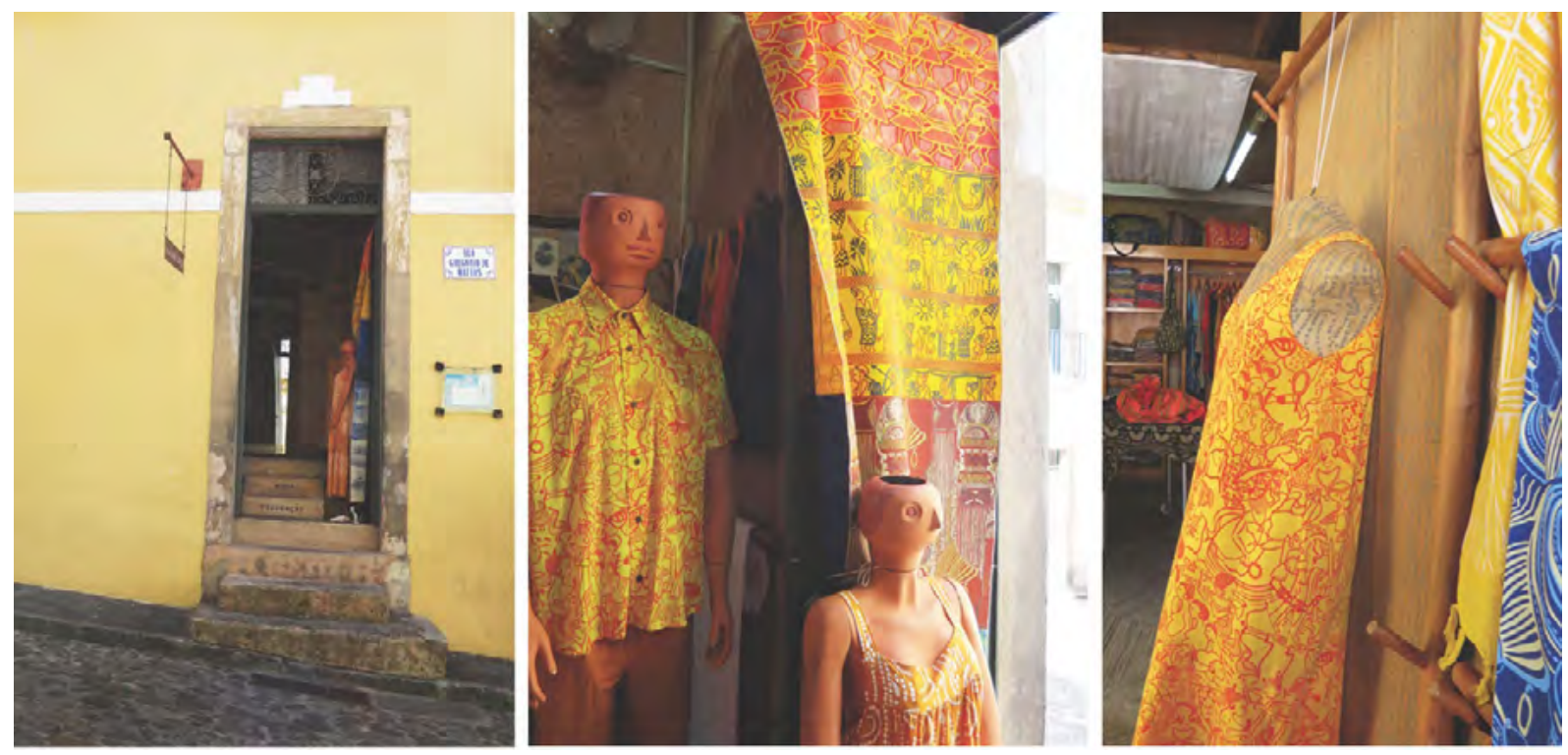

FONTE: A autora. Fachada e detalhes internos da loja física da marca Goya Lopes Design Brasileiro.

Salvador, Bahia: 2018. Imagens obtidas durante pesquisa de campo.

A escolha de trabalhar sua estética vinculada principalmente com temas culturais que contam histórias da diáspora africana fez com que Goya sistematizasse elementos da estamparia, como o traço e a cor, como sendo o destaque de suas criações. "Então, eu fazia aquilo que queria. Isso me deu a possibilidade de ousar, fazer. $E$ de me tornar uma referência" (informação verbal). ${ }^{15}$

A designer desenvolveu e desenvolve estampas que se transformam em têxteis e podem, na sequência, ser materializadas em artefatos de vestuário, como panôs, lenços, torços, turbantes, camisetas, camisas, vestidos, batas, saias, shorts, calças, cangas, bolsas, sacolas e sapatos, e de decoração, como colchas, jogos americanos, toalhas, capas de almofadas e papel de parede, entre outros. Um recorte da variedade de sua produção está retratado na figura 3.

${ }^{15}$ Entrevista de Goya Lopes, Salvador, janeiro de 2018. 
FIGURA 3 - ARTEFATOS DE GOYA LOPES

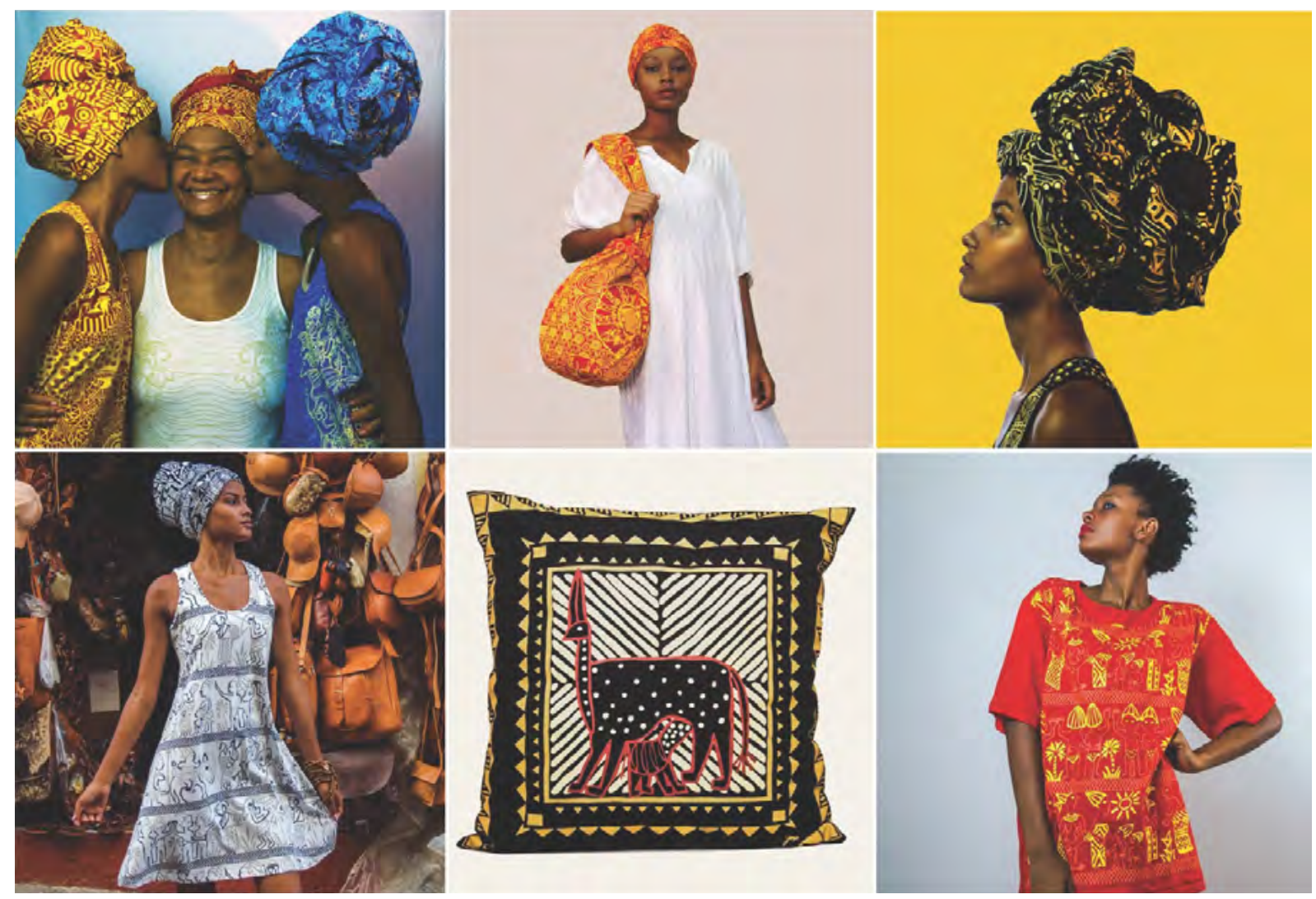

FONTE: LOPES, Goya. Artefatos da marca Goya Lopes Design Brasileiro. Salvador, Bahia: 2017.

Imagens obtidas em rede social da marca Goya Lopes Design Brasileiro.

Disponível em: https://www.instagram.com/goyalopesdesignbrasileiro. Acesso em: 1. mar. 2020.

Goya investiu na construção de sua própria estrutura de produção, um edifício de três andares feito aos poucos no quintal da casa do seu falecido pai. Nele eram realizados os seus desenhos manuais dos motivos, a vetorização das estampas, a elaboração da modelagem das peças, a estamparia em serigrafia localizada e corrida, o corte e a costura dos têxteis, a embalagem, o estoque e o acervo.

Acervo no sentido de salvaguardar as criações e os processos de criação: a designer organiza em seu espaço araras e manequins com peças de coleções passadas e recentes; estante com fichários de amostras de tecidos estampados, separados por coleção e ano; além de estantes e armários com os desenhos originais de cada estampa feita em papel, armazenados de acordo com a coleção (figura 4). A prática do acervo vem da experiência de Goya com a conservação de obras de arte - algumas de suas obras como artista plástica também se encontram nesse espaço -, atuando dessa maneira, mais uma vez ela transpõe as margens das disciplinas de design, moda e arte. Essa prática não é comum entre designers profissionais, mas entre aqueles que têm outra formação ou experiência com os procedimentos usuais de tratamento de conservação de obras de arte. 
FIGURA 4 - PRODUÇÃO E ACERVO DE GOYA LOPES
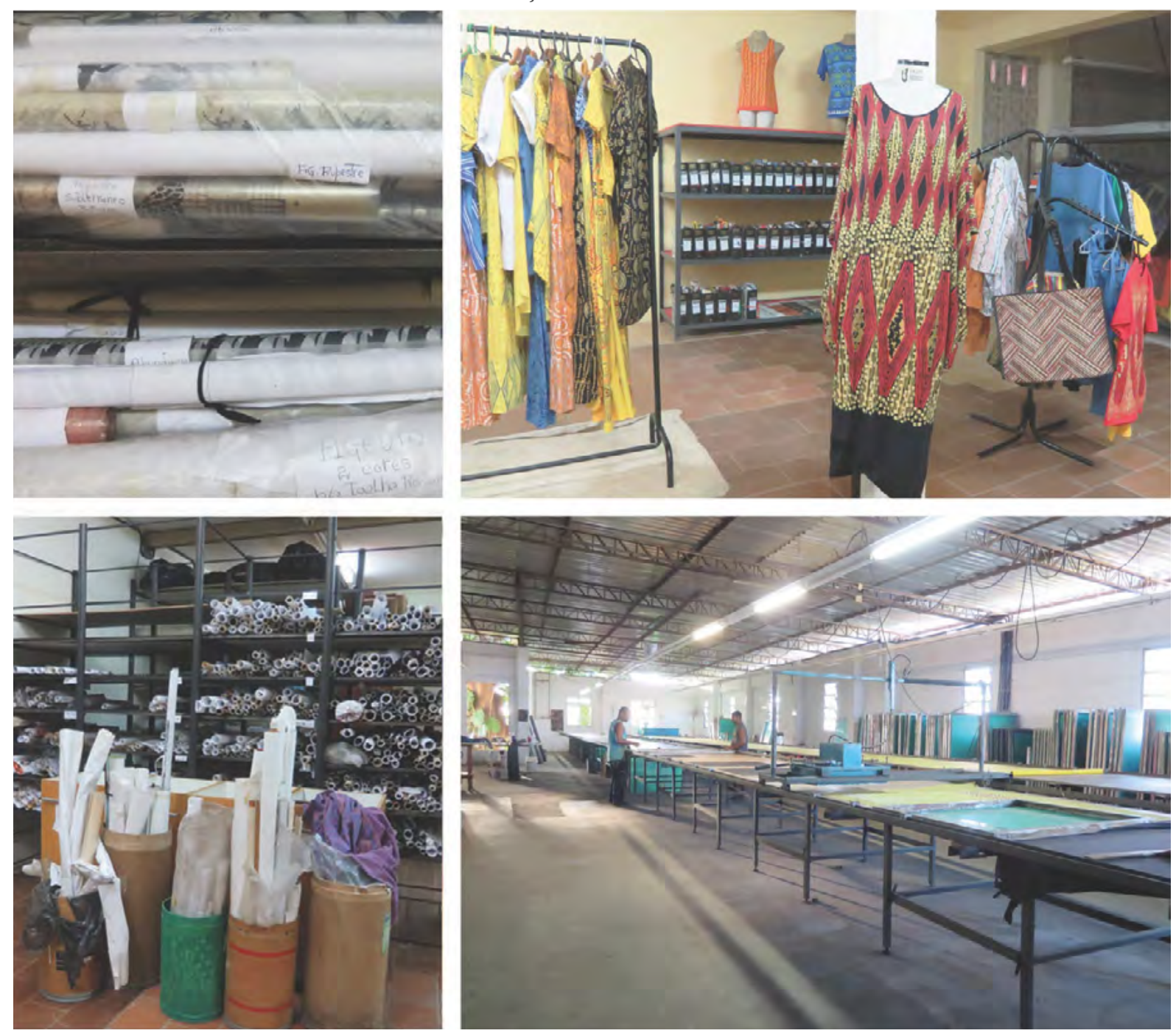

FONTE: A autora. Detalhes da produção e do acervo da marca Goya Lopes Design Brasileiro. Salvador, Bahia: 2018. Imagens obtidas durante pesquisa de campo.

A empresa Didara Indústria Comércio e Serviços de Confecções Ltda. teve, nos momentos de maior movimento, um porte grande e contou com uma equipe de 28 funcionários. Quando em expansão, possuía três lojas físicas na Bahia, tendo sido a primeira no centro antigo de Salvador, a segunda no aeroporto da cidade e a terceira em Porto Seguro; executava projetos em parceria com lojas multimarcas que comercializavam suas peças na Praia do Forte, Sauípe, Trancoso, Arraial d'Ajuda, São Paulo e Brasília; além de ter exportado para os Estados Unidos da América, a Espanha e a Itália.

Em paralelo, Goya continuou exercendo atividades relacionadas à sua formação como artista plástica, participando de exposições, pintando murais, criando painéis de mosaico, 
cenários e figurinos. Conquistou grande destaque em parcerias com artistas e grupos culturais, criando, a partir de 1990, figurinos para o cantor jamaicano Jimmy Cliff - colaboração de uma década -, para os cantores Moraes Moreira e Gilberto Gil, as cantoras Angelique Kidjo e Virgínia Rodrigues, as bandas Araketu e Banda Eva e orquestras, além de grupos teatrais, como o Bando de Teatro Olodum, e a atriz Sônia Braga.

Em seu currículo, Goya organiza uma categoria denominada "ambientação" na qual lista projetos criados a convite de espaços e eventos políticos e culturais. Destacamos aqui a ambientação da sala em que o presidente Itamar Franco recepcionou os presidentes ibero-americanos em Salvador, em 1993, a sala em que o presidente Fernando Henrique Cardoso tomou posse no Itamaraty, em Brasília, em 1995, e os ambientes da II Conferência de Intelectuais da África e da Diáspora nas salas do presidente Lula, do ministro Gilberto Gil e da ministra Matilde Ribeiro, em Salvador, em 2006.

\section{Precursora da moda afro-brasileira}

Goya entende que o seu padrão é diferente do africano pois ela aborda temas sobre a "diáspora africana e o aculturamento das diferentes etnias no Brasil" (LOPES; FALCÓN, 2010, p. 6). A identidade visual de suas estampas se dá em grande parte pelo uso das cores (figura 5), tonalidades diversas daquelas utilizadas nas estampas de origem africana. Ela explica que sua "cor é tropical, mas não africana. E meu trabalho indica que o pessoal da Bahia quer voltar para a ancestralidade, mas com um olhar na contemporaneidade" (LOPES citada por BUENO, 2015, p. 25). A designer afirma contar em artefatos de moda e decoração a história "da nossa gente, do nosso cotidiano, da nossa luta, cor local e dos ancestrais" (LOPES, 2016, p. 27).

\section{FIGURA 5 - TEMAS E CORES DE GOYA LOPES}
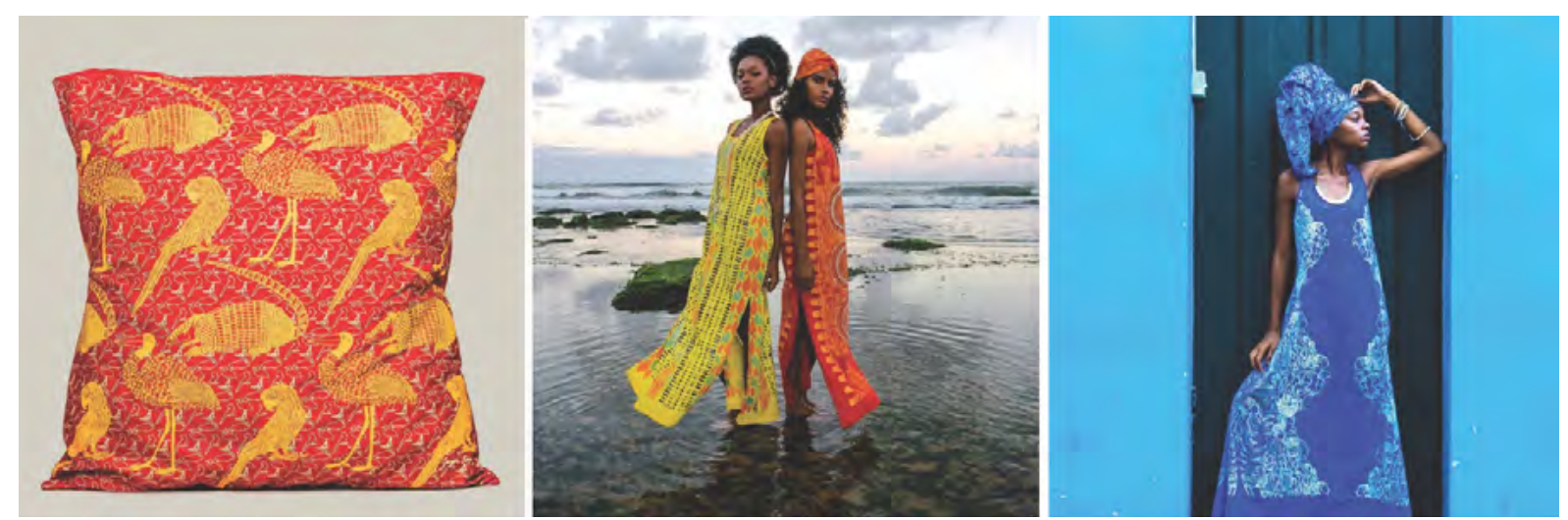

FONTE: LOPES, Goya. Temas e cores de Goya Lopes em seus artefatos. Salvador, Bahia: 2017.

Imagens obtidas em rede social da marca Goya Lopes Design Brasileiro.

Disponível em: https://www.instagram.com/goyalopesdesignbrasileiro. Acesso em: 1. mar. 2020. 
Goya conta que foi intitulada como pioneira ao definir seu trabalho como afro-brasileiro ou afro-baiano. Ela explica que era comum as pessoas chamarem suas criações de africanas ou afro, no entanto, afirma que a sua produção

tem toda uma conotação de influência tanto da matriz africana como a mais forte, mas o desenho tem tanto uma influência indígena, quanto uma influência europeia, tem até algumas modalidades que não são africanas. (INFORMAÇÃO VERBAL) ${ }^{16}$

Lopes considera suas criações um caldeirão, em que mescla essa diversidade social e cultural que forma o povo brasileiro.

O livro Imagens da Diáspora (2010), de autoria de Goya Lopes e Gustavo Falcón (professor da Universidade Federal da Bahia, doutor em História e jornalista) tem como base a exposição de Goya na Glass Curtain Gallery, do Columbia College Chicago (Estados Unidos), realizada em 2008, intitulada Ancestralidade africana no Brasil. A publicação reúne imagens de estampas e textos que integraram a mostra, apresentando categorias utilizadas pela designer para tratar de temas relacionados à diáspora africana, como africanidade, afro-brasilidade e afro-baianidade.

A cada categoria, a autora e o autor trazem conteúdos que consideram chave para a apresentação de um panorama de práticas culturais. Em africanidade, falam sobre arqueologia e solidariedade, a árvore da vida e cenas do cotidiano, estética e tecelagem, arte do cotidiano e máscaras sagradas, alegria e tráfico e tumbeiro. Em afro-brasilidade, abordam os temas de africanos e africanas que chegam ao Brasil e seus modos de viver atravessados pelo sofrimento e pelo castigo, pelo trabalho escravo, mas também a união e a resistência em forma de quilombos e congos, crioulas e quituteiras, abolição e os retornados.

Em afro-baianidade, tratam do processo da descolonização africana e da população negra no Brasil, "reconhecendo seu legado africano e reivindicando a sua identidade" (LOPES; FALCÓN, 2010, p. 36), destacando os penteados afro e afrodescendentes, a arte popular e a arte contemporânea na valorização de sua estética, a influência da religiosidade na constituição da sociedade brasileira, a gastronomia, a sensualidade e a manifestação cultural por meio dos tambores. Os autores ressaltam o complexo movimento de troca e intervenção de costumes que foi realizado no contexto da diáspora africana no Brasil, especialmente na Bahia.

Goya localiza sua empresa como criadora de moda afro-brasileira para todas as pessoas, "para todos aqueles que respeitam, que acreditam, gostam da cultura afro-brasileira e encontram nela um referencial de riqueza e de potencial, não só de luta, mas [..] de referência de sustentabilidade, de religiosidade e, principalmente, de um jeito de ser" (LOPES citada por GELEDÉS, 2016), e entende que a construção individual como artista e designer não é suficiente. Afirma que, há alguns anos,

${ }^{16}$ Entrevista de Goya Lopes, Salvador, janeiro de 2018. 
um lado é o empresarial, o outro é o cultural. É fundamental que eu tenha os pés nesses dois lugares para que, assim, eu possa mobilizar. Não adianta você crescer sozinho, porque chega-se a um ponto em que não se consegue discutir, não se consegue melhorias. (LOPES, 2012)

Lopes destaca a importância de se criar estratégias para que a produção afro-brasileira pertença ao circuito oficial do design de moda e seja conhecida, ressaltando a criação de um grupo unido como fundamental para que as mudanças ocorram. Ela exemplifica a complexidade desse pertencimento, incentivo e funcionamento pleno de uma empresa com o relato de sua participação no curso de empreendedorismo da Endeavor, em 2016. Realizado em parceria com o Banco Interamericano de Desenvolvimento e o Programa de Apoio a Empreendedores Afro-Brasileiros, tratava-se de um curso on-line com quatro meses de duração para 40 microempresárias e microempresários afro-brasileiros produzirem estruturas melhores para seus modos de trabalho.

A proposta era interessante, porém não totalmente eficaz. Goya Lopes ressaltou, como feedback às instituições organizadoras, que existem fatores concretos que influenciam na melhoria do trabalho de pessoas afro-brasileiras, como a mídia positiva de suas produções, que deveria ser contínua. Uma vez que existe a dependência dessa divulgação para se ter retorno financeiro e poder de compra, que, por sua vez, influenciam em maior volume de produção e distribuição, incluindo como consequência aporte financeiro para investir em mídia.

Como continuação desse tema, Lopes pontua que é conhecida por especialistas e não pelo mercado. Ela considera que o motivo disso é a ausência de um "tripé bem posicionado" (informação verbal) ${ }^{17}$, composto por produção, distribuição e mídia positiva. Ressalta que não é por falta de interesse em participar do mercado, mas sim porque sua entrada (a entrada de uma designer, microempresária afro-brasileira que produz peças com temática afro-brasileira) e sua permanência no mercado do design (design de moda) dependem do tripé bem posicionado e sua experiência é atravessada pelo racismo.

A designer afirma que "as pessoas ainda têm muito preconceito. Estamos sempre sendo [convidados] para situações pontuais, nada normal" (informação verbal) ${ }^{18}$, referindo-se aos convites para participar de alguns circuitos em poucos momentos, especialmente no mês de novembro por causa das datas relacionadas ao dia ou ao mês da consciência negra no Brasil:

Porque vê que [...] vai ser sempre um empecilho, pontual, então você é convidada pra situações pontuais. Ser convidada, lembrada, quando? Em novembro ou situações pontuais [...] então essa questão passa por uma, uma questão de ordem [...] na conjuntura atual de preconceito, racismo (INFORMAÇÃO VERBAL) ${ }^{19}$

\footnotetext{
17 Entrevista de Goya Lopes, Salvador, janeiro de 2018.

${ }^{18}$ Entrevista de Goya Lopes, Salvador, janeiro de 2018.

19 Entrevista de Goya Lopes, Salvador, janeiro de 2018.
} 
Sua fala explicita como o preconceito racial é presente e estruturante na sociedade brasileira de herança escravocrata e se apresenta como um obstáculo concreto para a ascensão de pessoas negras. Em uma sociedade como a nossa, "pessoas negras vão experienciar racismo do lugar de quem é objeto dessa opressão, do lugar que restringe oportunidades por conta desse sistema de opressão" (RIBEIRO, 2017, p. 86). Sandra Azerêdo afirma que todos os grupos possuem relação com a marcação de raça, ela é estabelecida por meio de relações de poder e "imposta aos grupos como se fosse natural" (AZERÊDO, 1994, p. 204); a autora atenta que, mesmo entre pesquisadoras feministas, as questões raciais no Brasil geralmente ficam como responsabilidade das mulheres negras, como se apenas pessoas negras fossem identificadas pelo marcador de raça, criticando a essencialização desse sistema de diferenciação e dominação.

Goya entende as restrições que o racismo impõe à circulação de seus desenhos e dela mesma, contudo, encontra em sua experiência momentos em que esse impedimento pôde ser transposto, como a sua participação em alguns eventos e espaços culturais e artísticos do design e da moda. Mas, por outro lado reconhece:

Agora, vai dizer, cê vê, o problema a esse nível? Eu nunca tive. Por uma questão: porque sempre fiquei no meu lugar, onde me chamavam eu ia, mas eu nunca tive a condição de tá lá pra ver, sabe? Mas sempre que me chamavam eu ia, respondo, mas é pontual. Isso que eu tava dizendo, isso é pontual. Não tem como você entrar, você não consegue entrar [...] (INFORMAÇÃO VERBAL) ${ }^{20}$

O relato de que a dinâmica de trabalho passa por "ficar no seu lugar", aguardar convites para participar dos eventos para os quais era chamada e ao mesmo tempo não poder participar dos espaços de tomada de decisão mostra os enfrentamentos cotidianos de uma mulher negra, artista, designer e empresária. A pesquisadora Djamila Ribeiro, em diálogo com a obra de Angela Davis, discorre sobre a necessidade de se "pensar projetos, novos marcos civilizatórios para que pensemos em um novo modelo de sociedade" (RIBEIR0, 2017, p. 13), uma sociedade menos desigual. Uma das maneiras para que isso ocorra é "divulgar a produção intelectual de mulheres negras, colocando-as na condição de sujeitos e seres ativos que, historicamente, vêm pensando em resistências e reexistências" (RIBEIR0, 2017, p. 14). Djamila convoca-nos para olhar que essas mulheres "estavam produzindo insurgências contra o modelo dominante e promovendo disputas de narrativas" (RIBEIRO, 2017, p. 24).

\section{Uma mulher negra no Colegiado Setorial de Moda}

Lopes (2016) conta que procurou alinhar, em sua trajetória, o discurso e a prática; a partir da pesquisa documental, pudemos observar que graças à sua consciência social e à sua produção constante com temas afro-brasileiros, algumas organizações com

20 Entrevista de Goya Lopes, Salvador, janeiro de 2018. 
causas relacionadas à cultura negra, como a Geledés ${ }^{21}$, identificam-na como uma importante figura feminina negra atuando na comunicação de histórias da cultura afro-descendente. 0 processo de conscientização de Goya sobre os impedimentos apresentados aos grupos aos quais ela pertence resulta no seu interesse em participar de associações, redes e sindicatos para buscar melhorias:

Não sei se os outros pensam da mesma maneira que eu, mas ela é necessária
exatamente para a construção atual. Hoje, tudo é na base de redes. Se você não
está associado a um grupo, você próprio não se reconhece. É fundamental que a
questão empresarial esteja aliada a grupos. E é fundamental, também, que esses
grupos não sejam fechados, que estejam relacionados com outras redes, porque
isso é o oxigênio. As coisas são muito rápidas, e a única maneira de estar atuali-
zado é fazendo parte desses grupos. Ninguém consegue absorver tudo. (LOPES
citada por BUENO, 2015, p. 28)

Sua participação e a organização em grupos tiveram início há 24 anos. Em 1996, ela se associou ao Sindicato de Vestuário de Salvador, tendo colaborado, durante 19 anos, em diversos cargos, a saber, terceira secretária, conselheira, diretora de responsabilidade social e diretora de moda. Paralelamente, integrou a Associação Bahia Design, de 1999 a 2010, como vice-diretora, conselheira e diretora-geral. Ainda nos anos 2000, a partir de 2004, envolveu-se na governança do Arranjo Produtivo Local de Salvador.

Em 2008, a designer foi convidada pelo Ministério da Cultura do Brasil (MinC) para colaborar com um grupo de trabalho cujo objetivo era criar o Colegiado Setorial de Moda do Conselho Nacional de Política Cultural, em Brasília (Distrito Federal). Sobre o convite, Goya diz ter sido chamada graças a um posicionamento do ministro da cultura em exercício, Juca Ferreira $^{22}$, nascido em Salvador e conhecido por atuar em projetos ligados à área cultural e de valorização do Nordeste brasileiro.

Nesse momento, o Plano Nacional de Cultura estava em desenvolvimento pela equipe do Ministério da Cultura, durante o segundo mandato do governo do presidente Luiz Inácio Lula da Silva (2007 a 2011); tratava-se de um "plano de estratégias e diretrizes para

\footnotetext{
${ }^{21}$ Organização de mulheres negras mais expressiva do Brasil, que caracteriza bem a importância das instâncias autônomas na conformação de ONGs. A liderança mais significativa do Geledés, Sueli Carneiro, integrou as primeiras arenas participativas conquistadas pelo movimento feminista: o Conselho da Condição Feminina e o Conselho Nacional da Mulher. Seguindo o caminho aberto por essa organização paulista, vários outros coletivos passaram por um processo de formalização jurídica, ganhando dimensões mais complexas e garantindo maior profissionalização e especialização do ativismo (RIOS citada em AVELAR; BLAY, 2017).

${ }^{22}$ Nasceu em Salvador, sociólogo e político. Vereador de Salvador em 1993 e em 2000. Em 2003, foi chamado pelo então ministro Gilberto Gil para o cargo de secretário-executivo do Ministério da Cultura, que exerceu por cincos anos, até a saída de Gil e o convite para assumir como ministro da cultura, de 2008 a 2010. Foi ministro da cultura novamente em 2015. Disponível em: http://www. cultura.mt.gov.br/-/juca-ferreira-e-o-novo-ministro-da-cultura. Acesso em: 2 fev. 2020.
} 
executar políticas públicas" (MINISTÉRIO DA CULTURA, 2009, p. 12) pautado no "dever de fomentar o pluralismo e promover equidade no acesso à produção e ao usufruto dos bens e serviços culturais" (MINISTÉRIO DA CULTURA, 2009, p. 12). Na apresentação dos objetivos, constava que "os desequilíbrios entre regiões e as desigualdades sociais - realimentadas por discriminações étnicas, raciais e de gênero - também atravessam a construção do País" (MINISTÉRIO DA CULTURA, 2009, p. 12) e que por meio do plano buscariam abranger as demandas culturais da população.

Os objetivos do Plano Nacional de Cultura têm correspondências com a teoria feminista negra com a qual dialogamos. Recorremos novamente à Djamila Ribeiro (2017) que, em seu livro, ao trazer o trabalho da filósofa panamenha Linda Alcoff, diz que devemos ter atenção ao processo de descolonização do conhecimento para focar na identidade social, "não somente para evidenciar como o projeto de colonização tem criado essas identidades, mas para mostrar como certas identidades têm sido historicamente silenciadas e desautorizadas no sentido epistêmico, ao passo que outras são fortalecidas" (RIBEIRO, 2017, p. 29).

0 documento consultado sobre o Plano Nacional de Cultura registra que foram cerca de cinco mil participantes - gestores de instituições culturais públicas e privadas, representantes de produção e difusão das artes, técnicos, produtores, artesãos, empreendedores, intelectuais, legisladores, militantes de movimentos sociais, representantes de comunidades tradicionais - nos seminários promovidos pelo governo. As e os participantes foram divididos em cinco grupos de trabalhos (GTs) para debater os cinco eixos mapeados pelo governo, a saber, eixo um: fortalecer a ação do Estado no planejamento e na execução das políticas públicas culturais; eixo dois: incentivar, proteger e valorizar a diversidade artística e cultural brasileira; eixo três: universalizar o acesso à fruição e à produção cultural; eixo quatro: ampliar a inserção da cultura no desenvolvimento socioeconômico sustentável; e eixo cinco: consolidar os sistemas de participação social na gestão das políticas culturais. Como resultado, cada GT sugeriu mudanças em forma de relatório, que foi novamente analisado e formulado para se tornar projeto de lei e colocado em votação no Congresso Nacional.

Em 2009, Goya recebeu o segundo convite, agora para integrar um grupo de trabalho com o objetivo de criar o Colegiado Setorial de Moda, uma das iniciativas pertencentes ao Conselho Nacional de Política Cultural (CNPC). O Conselho era uma "instância de participação social colegiada que compõe o Sistema Nacional de Cultura e integra a estrutura básica do Ministério da Cultura" (MINISTÉRIO DA CULTURA, 2015, p. 8), composto por plenário, comitê de integração de políticas culturais, colegiados setoriais, comissões temáticas ou grupos de trabalho e Conferência Nacional de Cultura.

Os setores representados por meio dos colegiados setoriais eram de 14 áreas técnico-artísticas, a saber: moda; artes visuais; música; teatro; dança; circo; audiovisual e literatura; literatura, livro e texto; leitura e literatura; arte digital; arquitetura e urbanismo; design; artesanato e cultura hip hop. Além de 11 setoriais das áreas de patrimônio cultural: expressões artísticas culturais afro-brasileiras; culturas dos povos indígenas; culturas populares; arquivos; patrimônio material; patrimônio imaterial; capoeira; cultura alimentar; culturas quilombolas; culturas dos povos e comunidades tradicionais de matriz africana; e museus (MINISTÉRIO DA CULTURA, 2015). 
Lopes conta que os GTs foram organizados por regiões (Norte, Nordeste, Centro-Oeste, Sul e Sudeste) e também por áreas, e que para o setor da moda foram convidados algumas empresas, associações e designers, como Arezzo, Paulo Borges e Ronaldo Fraga. A designer lembra dos embates que aconteciam por causa das diferenças de atuação das pessoas envolvidas - "tem uma distância entre o que é cultural e o que é moda, da conjuntura moda-mercado" (informação verbal) ${ }^{23}$ - e diz que, do mercado, ela foi a única que conseguiu agenda para participar mais ativamente. Ao compreender a necessidade de se ter um coletivo de pessoas com reivindicações similares para equilibrar o debate, sugeriu que o próximo encontro fosse na Bahia, em Salvador.

Os debates no GT foram aprofundados durante o I Seminário Nacional de Moda e Cultura realizado em Salvador, do qual participaram representantes dos eixos criativos, produtivos e institucionais e um grupo de criadores e criadoras que faziam moda afro-brasileira. Ela foi eleita como representante do eixo criativo para o Colegiado Setorial de Moda e assumiu como membro titular no ano de 2010, para o mandato de duração de dois anos (LOPES, 2016; informação verbal ${ }^{24}$. Essa oportunidade converge com suas demandas de reflexão e de mobilização no design para o crescimento e o fortalecimento da identidade cultural da moda brasileira, sendo possível iniciar o trabalho com políticas públicas para a moda como cultura (LOPES citada por BUENO, 2015).

Em 2011, Goya Lopes, da Bahia, Fátima Negrann ${ }^{25}$, do Rio de Janeiro, Makota Kizamdembu $^{26}$, de Minas Gerais, que já se articulavam desde o I Seminário Nacional de Moda e Cultura, formaram o grupo de trabalho sobre moda afro-brasileira com Edson Luiz ${ }^{27}$, de São Paulo, e Graça Santos ${ }^{28}$, do Distrito Federal, pois enxergavam a necessidade de valorizar a moda afro-brasileira perante a moda brasileira:

\footnotetext{
23 Entrevista de Goya Lopes, Salvador, janeiro de 2018.

24 Entrevista de Goya Lopes, Salvador, janeiro de 2018.

${ }^{25}$ Fundadora e membro da Coordenação Executiva Nacional da Associação Nacional da Moda Afro-Brasileira (Anamab). Proprietária da empresa Empório Afro Roupas \& Acessórios. Estilista que trabalha com a releitura da moda africana transformando cada peça em arte. Gestora de eventos culturais. Disponível em: http://associacaodamodaafrobrasileira.blogspot.com. Acesso em: 2 fev. 2020.

26 Proprietária da empresa TC Arte Produções. Empresária, residiu em vários estados do Brasil pesquisando a cultura de matriz africana. Cursou Moda, é mestre em Indumentária, designer de moda e figurinista. Disponível em: http://associacaodamodaafrobrasileira.blogspot.com.

Acesso em: 2 fev. 2020.

${ }^{27}$ Fundador e membro da Coordenação Executiva Nacional da Nacional da Moda Afro-Brasileira (Anamab) . Formado em Engenharia Mecânica e em Engenharia de Produção. Ex-diretor do Coletivo de Empresários e Empreendedores Afro-Brasileiros. Disponível em: http://associacaodamodaafrobrasileira.blogspot. com. Acesso em: 2 fev. 2020.

28 Fundadora da Anamab. Proprietária da empresa Instituto Afrozinga, o primeiro salão de beleza especializado em cuidar de cabelos crespos na cidade de Brasília. Disponível em: http://associacaodamodaafrobrasileira.blogspot.com.html. Acesso em: 2 fev. 2020.
} 
Temos um grupo de trabalho e estamos estudando a forma de apresentar para a sociedade elementos para que se perceba que essa moda tem um conteúdo cultural e um potencial de imagem muito grande. É preciso haver uma crítica positiva da mídia. Essa moda é muito promissora, mas hoje ela não está sendo vista dessa maneira. (LOPES citada por BUENO, 2015, p. 27)

O movimento para formar um GT específico sobre moda afro-brasileira condiz com outra pauta do feminismo negro: nomear. "Se não se nomeia uma realidade, sequer serão pensadas melhorias para uma realidade que segue invisível" (RIBEIRO, 2017, p. 41). Para a filósofa Djamila Ribeiro, o ato de nomear, definir, contribui para fortalecer e demarcar.

Enquanto o GT seguia com a sua produção, houve a mudança de gestão do Governo Federal em 2011 e, em 2012, foi criada pela presidente Dilma Rousseff e a equipe do Ministério da Cultura, comandada por Ana de Hollanda, a Secretaria de Economia Criativa. No documento público no qual são apresentadas as políticas, diretrizes e ações da secretaria é possível identificar um posicionamento preocupado com uma discussão que se pretende decolonial. A ministra afirma o interesse em celebrar e fomentar a diversidade cultural do povo mestiço do Brasil e apresenta, entre outros movimentos históricos, o projeto político de Lina Bo-Bardi, o museu-escola como fomento ao design brasileiro: o Museu de Arte Popular da Bahia, de 1963; a Secretaria busca "levar em conta o que historicamente descartamos e excluímos" (MINISTÉRIO DE CULTURA, 2011, p. 13).

Nesse documento, identificamos falas convergentes à teoria defendida por Campi (2003) sobre repensar a responsabilidade histórica do país, considerando a construção de outros modelos de economia com base em um conhecimento não-colonial, valorizando diferentes regiões como centros de produção de cultura. Como exemplo, temos o evento da instalação do Centro Internacional das Indústrias Criativas, em Salvador (Bahia), indicado no Fórum Internacional das Indústrias Criativas - formado por governos de duas dezenas de países - como um local potencial para a ascensão industrial; e a decisão de escolher Cláudia Leitão ${ }^{29}$, uma mulher nordestina como responsável pela Secretaria de Economia Criativa. Também vemos o que o movimento feminista negro nos desperta sobre os saberes que são produzidos por "indivíduos de grupos historicamente discriminados, para além de serem contra discursos importantes, são lugares de potência e configuração do mundo por outros olhares e geografias" (RIBEIRO, 2017, p. 75).

Durante os anos de 2012 e 2014, Goya Lopes segue como membro titular do Colegiado Setorial de Moda do MinC em um novo mandato e se interessa em desenvolver com o GT sobre moda afro-brasileira reflexões acerca de "como reconhecer a moda afro-brasileira, quem são os seus autores, quem somos nós nesse momento" (LOPES, 2012). 0 que parece conversar com a proposta da matriz estratégica da secretaria.

\footnotetext{
${ }^{29}$ Graduada em Direito e em Educação Artística, mestre em Sociologia Jurídica e doutora em Sociologia. Como pesquisadora, foi consultora ad hoc do Conselho Nacional de Desenvolvimento Científico e Tecnológico (CNPq). Foi secretária da Cultura do Estado do Ceará (2003-2006) e responsável pela criação e primeira gestora da Secretaria de Economia Criativa (SEC) do MinC. É consultora em Economia Criativa para a Organização Mundial do Comércio (OMC) e para a Conferência das Nações Unidas para o Comércio e Desenvolvimento (UNCTAD). Disponível em: http://fjmangabeira.org.br/economiacriativa/ dt_team/claudia-leitao. Acesso em: 2 fev. 2020.
} 
Na matriz estratégica Setores criativos $x$ desafios da economia criativa desenvolvida pela Secretaria de Economia Criativa, na etapa do levantamento de demandas com profissionais dos setores criativos, havia representantes setoriais do MinC/CNPC de áreas como artesanato, culturas populares, culturas indígenas e culturas afro-brasileiras. No segmento de culturas afro-brasileiras, os desafios mapeados pelo Governo Federal foram:

Criar mecanismos de ações afirmativas que contemplem projetos promovidos por proponentes afro-descendentes e a produção cultural negra, no Fundo Nacional de Cultura no segmento da diversidade, além de editais promovidos pelas estatais; apoiar a produção, a difusão e distribuição dos produtos culturais negros para os eventos nacionais e internacionais; criação de uma Feira Nacional de Cultura Negra para promover intercâmbio e negócios entre empreendimentos negros; garantir a apropriação dos marcos regulatórios político-jurídicos já existentes que interessam à comunidade afro-brasileira. (MINISTÉRIO DE CULTURA, 2011, p. 139).

Observamos que os desafios identificados pelo governo são semelhantes àqueles citados por Goya, envolvendo principalmente produção, distribuição e difusão de iniciativas e artefatos produzidos por pessoas afro-descentes e/ou com a temática afro-brasileira, além dos impedimentos sentidos por ela materializados em preocupação jurídica do governo e no desafio de garantir os marcos regulatórios para a comunidade afro-brasileira.

Ainda na matriz estratégica estavam representantes setoriais do MinC/CNPC nas áreas de artes visuais, livro-leitura e literatura, arquitetura e moda, entre outros. Os desafios em relação à moda foram:

Fomentar estudos e pesquisas que mapeiem, a partir do território, a interdisciplinaridade e diversidade da moda e potencializar as microrregiões com a realização de projetos de moda; elaborar editais públicos específicos para o setor de moda e fomentar parcerias com órgãos públicos e privados para a consolidação das atividades de grupos acadêmicos, experimentais e oriundos da sociedade civil organizada com ações nacionais e internacionais; promover a articulação interministerial para formação e qualificação do profissional de moda; estimular a circulação e comercialização de produtos e serviços; criação do Fundo Nacional da Moda e do Comitê da Moda. (MINISTÉRIO DE CULTURA, 2011, p. 145)

Nesse caso, vemos congruência na ação de mapear a fim de potencializar outros eixos de produção de moda no Brasil e no estímulo à comercialização de produtos e serviços. Para Goya e o GT sobre moda afro-brasileira, o mapeamento é necessário, pois diversos atores da moda afro-brasileira agem de maneira isolada por não se conhecerem, mostrando assim a importância de uma mobilização coletiva.

Apesar de as propostas do Plano Setorial de Moda nesses dois momentos se apresentarem abrangentes e desejosas de contemplar uma diversidade cultural mais ampla, algumas questões afro-brasileiras levantadas pelo GT sobre moda afro-brasileira não eram tidas como pertinentes pelo plano. Na época, o Colegiado Setorial de Moda indicou a Goya Lopes, 
Fátima Negrann e Makota Kizandembu que recorressem à Fundação Palmares ${ }^{30}$ a fim de conceber uma associação nacional que pudesse se articular de forma mais ampla do que as organizações pontuais.

As integrantes e o integrante do GT entram com o processo de fundação da Associação Nacional da Moda Afro-Brasileira (Anamab) em 2012. Hoje, formada por eles e por Cynthia Mariah ${ }^{31}$, Ialê Garcia ${ }^{32}$, Angélica Moreira ${ }^{33}$, Michelle Fernandes ${ }^{34}$, Célia Sampaio ${ }^{35}$ e Wander Marcilio ${ }^{36}$, com o objetivo de auxiliar no desenvolvimento da moda afro-brasileira, organiza ações que fomentam encontros e parcerias, disseminam e promovem estudos e incentivos para conscientizar "os criadores da importância de se trabalhar dentro de um pensamento que valoriza a moda afro-brasileira” (ANAMAB, 2018; informação verbal) ${ }^{37}$.

Goya desenvolve e participa de atividades da Anamab e, em entrevista à autora, deu destaque para a palestra realizada no Afro Fashion Day ${ }^{38}$, em Salvador, em 2018, que fez com Angélica Moreira, coordenadora da Anamab no Estado da Bahia, quando abordaram o tema empreendedorismo; também ressaltou a oficina ministrada em Minas Gerais no mesmo ano, durante a qual apresentou detalhes do seu processo de criação de estampas. A intenção da associação é que as e os participantes se frequentem, viajem o país contando suas experiências e estimulando trocas.

\footnotetext{
30 Fundação Cultural Palmares, criada pelo Governo Federal em 1988 para promoção e preservação da arte e da cultura afro-brasileiras. Entidade vinculada ao Ministério da Cidadania. Emitiu mais de 2.476 certificações para comunidades quilombolas. O documento reconhece seus direitos e lhes dá acesso aos programas sociais do Governo Federal. É referência na promoção, no fomento e na preservação das manifestações culturais negras e no apoio e na difusão da Lei 10.639/03, que torna obrigatório o ensino da História da África e Afro-brasileira nas escolas. Disponível em: http://www.palmares. gov.br/?page_id=95. Acesso em: 2 fev. 2020.
}

31 Membro da Coordenação Nacional de Juventude da Anamab. Proprietária da empresa Cynthia Mariah. Estilista, produtora de moda e educadora cultural, formada em Design de Moda. Direcionou-se para a moda afro-brasileira, explorando o legado de cores existentes nas duas culturas, além do contexto histórico que carrega a cultura afro. Também é idealizadora da grife que leva seu nome desde 2006, na qual confecciona roupas e acessórios únicos e exclusivos. Disponível em: http://associacaodamodaafrobrasileira.blogspot.com. Acesso em: 2 fev. 2020.

32 Membro da Coordenação Executiva Nacional da Anamab. Proprietária da empresa Yalodê Moda Étnica. Disponível em: http://associacaodamodaafrobrasileira.blogspot.com. Acesso em: 2 fev. 2020.

${ }^{33}$ Representante da Bahia na Anamab. Proprietária da empresa Ajeum da Diáspora. Disponível em: http:// associacaodamodaafrobrasileira.blogspot.com. Acesso em: 2 fev. 2020.

${ }^{34}$ Representante de São Paulo na Anamab. Proprietária da empresa Krioula. Disponível em: http://associacaodamodaafrobrasileira.blogspot.com. Acesso em: 2 fev. 2020.

${ }^{35}$ Representante do Maranhão na Anamab. Proprietária da empresa Oyá, designer de moda, cantora. Disponível em: http://associacaodamodaafrobrasileira.blogspot.com. Acesso em: 2 fev. 2020.

${ }^{36}$ Representante de Minas Gerais na Anamab. Proprietário da empresa WM Atelier. Disponível em: http:// associacaodamodaafrobrasileira.blogspot.com. Acesso em: 02 de fev. 2020.

37 Entrevista de Goya Lopes, Salvador, janeiro de 2018.

38 O Afro Fashion Day é realizado pelo Jornal Correio com o apoio da prefeitura de Salvador, do Salvador Shopping, do Sebrae, da Vizzano e do Museu du Ritmo. Valoriza as marcas baianas que são produzidas por pessoas negras ou que evidenciam a cultura dessa população. Disponível em: https:// www.geledes.org.br/conceito-do- afro-fashion-day-2018-afirma-identidade-atraves-das-cores. Acesso em: 20 jan. 2020 . 
Ao ser questionada sobre como vê sua inserção no Colegiado Setorial de Moda, Lopes diz:

Fui chamada desde o primeiro momento, quando se pensou em fazer o Setorial. Pensaram exatamente na inclusão da diversidade, da pluralidade, e por eu ter um trabalho muito verdadeiro. Em relação ao trabalho, é exatamente a resposta daquilo que eu vivo, ou seja, o meu traço estava na minha ancestralidade. Então, a minha inclusão foi desde o início, porque eu iria representar essa situação. Eu percebi isso ao longo dos anos e depois quando foi renovado, que eu continuei também pela maneira com que eu me coloquei, me posicionei. Mas isso é claro que me fortaleceu, teve um fortalecimento para que eu pudesse junto com outras pessoas, fazer a Anamab. [...] Foi por ser mulher, negra, microempresária, criadora de um trabalho autoral, coerente com as raízes e por pensar que a moda deveria ter um novo olhar. (INFORMAÇÃO VERBAL) ${ }^{39}$

0 relato de Goya está em diálogo com mais uma pauta do movimento feminista negro: refutar uma universalidade. Ao possibilitar uma pluralidade de existências, de vozes, "o que se quer, acima de tudo, é quebrar com o discurso autorizado e único, que se pretende universal", trabalhar para descontinuar o "regime de autorização discursiva" (RIBEIRO, 2017, p. 69-70). Seu discurso comunicado por meio de seus desenhos, traços e estampas, suas falas e posicionamentos nas reuniões de estratégia do Setorial de Moda atuaram na ruptura de um discurso único.

A designer relata que sobre a articulação política, essa experiência foi marcante e alterou alguns modos de pensar e agir:

Uma coisa muito importante [...]: participar do Setorial de Moda mudou muito a minha visão sobre políticas públicas. Eu vi que políticas públicas são fundamentais para que a gente consiga situações positivas e foram conseguidas, como os editais, que estão devagar quase parando, mas que continuam. Um despertar para a questão moda, moda é cultura, isso foi realizado, e isso não tem retorno. Então, são coisas que eu vi ao longo desses anos no Setorial de Moda, a importância. É uma pena que parou e vamos ver se acontece em outro momento, mas para mim, pessoalmente, foi um despertar para as políticas públicas, ver a importância de que eu, euzinha, [...] posso fazer alguma coisa, não devo ficar esperando o outro. Eu acho que essa foi a coisa mais forte que aprendi ao longo desses anos. (INFORMAÇÃO VERBAL) ${ }^{40}$

Estar comprometida com as propostas, se aliar a outras pessoas que também lutam por diversidade e se engajar com elas é o que Goya entende da sua atuação como articuladora política no Colegiado Setorial de Moda, ressaltando constantemente que não fazemos nada sozinhos (LOPES, 2020).

\footnotetext{
${ }^{39}$ Entrevista de Goya Lopes, Salvador, janeiro de 2018.

40 Entrevista de Goya Lopes, Salvador, janeiro de 2018.
} 


\section{Considerações finais}

Como fechamento deste artigo, refletimos que, ao descrever eventos sobre algumas experiências de Goya Lopes, uma mulher negra, artista, designer, empresária, como articuladora política de um projeto de moda brasileira mais plural, buscamos apresentar uma trajetória de construção de discursos, posicionamentos, sentimentos de pertencimento a uma rede de relações.

O mapeamento de suas estratégias mostrou o processo de constituição de Lopes como profissional e como figura que representa pautas de mulheres negras e homens negros que trabalham com criação inspirados na temática afro-brasileira. A metodologia utilizada neste artigo permitiu uma compreensão mais abrangente das percepções de Goya Lopes acerca dos acontecimentos, as entrevistas mostraram-se profícuas para se obter dados que não estão registrados em fontes documentais, o acesso apenas foi possível graças à disponibilidade e à colaboração da designer com a pesquisa.

As questões de preconceito de região e de raça pautaram impedimentos na participação em eventos e espaços, não por causa da falta de capacidade da designer e sim por causa da ausência de autorização social. Mas também impulsionaram o entendimento da importância da articulação em grupos atravessados pelos mesmos constrangimentos na ressignificação em forma de potência.

\section{Referências}

ALBERTI, Verena. Manual de história oral. Rio de Janeiro: 2.ed. Brasil: Editora FGV. 2004.

ALPARGATAS. Conheça a empresa. Alpargatas. Disponível em: https://www.alpargatas. com.br/\#/conheca-empresa. Acesso em: 9 fev. 2020.

ANAMAB. Quem somos. Associação Nacional da Moda Afro-Brasileira. Disponível em: http://associacaodamodaafrobrasileira.blogspot.com/p/quem-somos_13.html. Acesso em: 5 jan. 2020.

ANAMAB. Quem somos: Angélica Moreira, Célia Sampaio, Cynthia Mariah, Edson Luiz, Fátima Negrann, Graça Santos, Goya Lopes, Ialê Garcia, Makota Kizamdembu, Michelle Fernandes e Wander Marcilio. Associação Nacional da Moda Afro-Brasileira. Disponível em: http:// associacaodamodaafrobrasileira.blogspot.com/p/quem-somos_13.html. Acesso em: 2 fev. 2020.

AVELAR, Lúcia; BLAY, Eva Alterman (orgs.). 50 Anos de feminismo: Argentina, Brasil e Chile: A Construção das Mulheres como Atores Políticos e Democráticos. 1. ed. 1. reimpr. São Paulo: Editora da Universidade de São Paulo, Fapesp, 2017.

AZERÊDO, Sandra. Teorizando sobre gênero e relações raciais. In: Relações sociais de gênero, raça e relações interétnicas. Estudos Feministas, ano 2, 2o semestre 1994. 
BONIFÁCIO, Bruna Carmona. Experiências de mulheres no design de superfície: narrativas sobre trabalho e trajetórias de Goya Lopes e Renata Rubim. 2019.197 f. Dissertação (Mestrado em Design) - Programa de Pós-Graduação em Design, Universidade Federal do Paraná, Curitiba, 2019. Disponível em: https://acervodigital.ufpr.br/handle/1884/62072. Acesso em: 2 fev. 2020.

BUENO, Ricardo. Alma brasileira. 3. ed. Porto Alegre: Quattro Projetos, 2015. 204 p.

CAMPI, Isabel. La historia y las teorías historiográficas del diseño. México: Editorial Designio, 2003.

CARDOSO, Rafael. Uma introdução à história do design. São Paulo: Editora Blucher, 2008.

FGV. Mauro Malin e Marcelo Costa em verbete biográfico sobre Severo Fagundes Gomes. [Rio de Janeiro]. Site. Disponível em: https://www.alpargatas.com.br/\#/conheca-empresa. Acesso em: 9 fev. 2020.

FORTY, Adrian. 0 lar. Objetos de desejo: Design e sociedade desde 1750. São Paulo: Cosac Naify, 2007.

LISBOA, Luis Fernando. Estilista baiana Goya Lopes aposta em mercado virtual. Geledés: Salvador, 25 fev. 2016. Disponível em: https://www.geledes.org.br/estilista-baiana-goyalopes-aposta-em-mercado-virtual. Acesso em: 5 mar. 2020.

NOELLE, Midiã. GELEDÉS. Conceito do Afro Fashion Day 2018 afirma identidade através das cores. Geledés: Salvador, 22 nov. 2018. Disponível em: https://www.geledes.org.br/ conceito-do-afro-fashion-day-2018-afirma-identidade-atraves-das-cores/. Acesso em: 20 jan. 2020.

LOPES, Goya. Site. Disponível em: https://goyalopes.com.br. Acesso em: 14 dez. 2018.

LOPES, Goya. Goya Lopes - Trajetória de uma criadora. In: ModaPalavra e-periódico. Florianópolis, ano 9, n.18, p. 20-42, jul./dez. 2016. ISSN 1982-615x. Disponível em: http:// www.revistas.udesc.br/index.php/modapalavra/issue/view/491. Acesso em: 24 fev. 2020.

LOPES, Goya; CASTELLÓN, Lena. A designer baiana Goya Lopes e suas criações. Geledés: Salvador, 2 jan. 2012. Disponível em: https://www.geledes.org.br/a-designer-baiana-goyalopes-e-suas-criacoes. Acesso em: 25 fev. 2020.

LOPES, Goya; FALCÓN, Gustavo. Imagens da diáspora. Salvador: Solisluna Design Editora, 2010. 80 p., il. - (Série Traços do Encantamento). 
LOPES, Maria Auxiliadora dos Santos Goya. Entrevista concedida. Salvador, BA. Janeiro de 2018.

LOPES, Maria Auxiliadora dos Santos Goya. Entrevista concedida. Salvador, BA. Fevereiro de 2020.

MEIHY, José Carlos Sebe Bom. Manual de história oral. 5. ed. São Paulo: Edições Loyola, 2005.

MILLER, Daniel. Trecos, troços e coisas: estudos antropológicos sobre cultura material. São Paulo: Zahar, 2013.

BRASIL, Ministério da Cultura. Por que aprovar o Plano Nacional de Cultura: conceitos, participação e expectativas. Brasília, DF: Ministério da Cultura, 2009. Disponível em: www. cultura.gov.br/pnc. Acesso em: 14 dez. 2019.

BRASIL, Ministério da Cultura. Plano da Secretaria da Economia Criativa: políticas, diretrizes e ações, 2011-2014. Brasília, DF: Ministério da Cultura, 2011. 1. edição revisada, p. 24.

BRASIL, Ministério da Cultura. Cartilha do Conselho Nacional de Política Cultural: o que é? Estrutura e atribuições. Brasília, DF: Ministério da Cultura, 2015. Disponível em: http:// cnpc.cultura.gov.br/publicacoes/. Acesso em: 1 fev. 2020.

MUSEU DA CASA BRASILEIRA. Site. Disponível em: http://www.mcb.org.br/pt- BR/ produtos/arte-nativa-aplicada-ana. Acesso em: 2 out. 2018.

PALMARES FUNDAÇÃO CULTURAL. Institucional. Disponível em: http://www.palmares. gov.br/?page_id=95. Acesso: 2 de fev. 2020.

PEREIRA, Rodrigo Mateus. Construção e design de guitarras nos anos 1960 e 1970 : narrativas sobre trabalho e trajetórias em São Paulo (SP) e Porto Alegre (RS). 2014. 145 f. Dissertação (Mestrado em Design) - Programa de Pós-Graduação em Design, Universidade Federal do Paraná, Curitiba, 2014.

RIBEIRO, Djamila. 0 que é lugar de fala?. Belo Horizonte: Letramento: Justificando, 2017. 112 p.; 15,9 cm. (Feminismos Plurais)

BRASIL, Assessoria de comunicação. Juca Ferreira é o novo ministro da Cultura. Secretaria de Estado de Cultura, Esporte e Lazer do Governo de Mato Grosso: Cuiabá, 2 jan. 2015. Disponível em: http://www.cultura.mt.gov.br/-/juca-ferreira-e-o-novo-ministro-dacultura. Acesso em: 2 de fev. 2020. 
SEMINÁRIO INTERNACIONAL ECONOMIA CRIATIVA COMO ESTRATÉGIA DE DESENVOLVIMENTO, Cláudia Leitão. Brasília, 2018. Disponível em: http://fjmangabeira. org.br/economiacriativa/dt_team/claudia-leitao. Acesso em: 2 fev. 2020.

\section{Agradecimentos}

Agradecemos à Goya Lopes pelo interesse e pela disponibilidade em participar da pesquisa de forma tão afetuosa. Agradecemos à Capes pela bolsa de estudos fornecida durante o período da pesquisa de mestrado da qual os dados deste texto se derivam. Sem o aporte financeiro não teria sido possível investigar e registrar as histórias de mulheres no design no Brasil, nem sequer fazer circular o conhecimento desenvolvido entre 2017 e 2019. 